\title{
РАННЬОМОДЕРНА ФІЛОСОФІЯ
}

\author{
Dmytro Sepetyi
}

\section{THE PROBLEM OF MIND-BODY INTERACTION AND THE CAUSAL PRINCIPLE OF DESCARTES'S THIRD MEDITATION}

René Descartes famously argued for the real distinctness of mind (soul) and body as two substances that have entirely different natures (their essences consist in different fundamental attributes, thought and extension) and can, in principle, exist separately. This doctrine is wellknown as «substance dualism». However, Descartes acknowledged the actual close causal relationship of mind and body - that certain physical states of the body (brain) cause certain states of the soul (sensations) and that certain (volitional) states of the soul cause certain physical processes in the body (some processes in the brain and, with their mediation, behaviour movements of parts of the body). In the contemporary philosophy of mind such a view is called «interactionism». Many Descartes's contemporaries and later philosophers considered the interaction between mind and body as a great problem for dualism generally and for Descartes's philosophy in particular. Descartes's responses and explanations on this point did not close the issue but gave rise to a number of more specific ones - about the tenability of theses responses, their coherence and correct interpretation. Such issues were much discussed in the philosophical literature on Descartes of the last several decades (to list just a small part of important publications dealing with this topic: [Radner 1971; 1985], [Wilson 1978; 1991], [Loeb 1981], [Richardson 1982; 1985], [Broughton 1986], [Bedau 1986], [O’Neill 1987], [Nadler 1994], [Gorham 2002; 2003], [Schmaltz 2008], [Hoffman 2009], [De Rosa 2013], [Nolan 2015], [Brown 2019], [Christofidou 2019]). In particular, it is still debated whether the acknowledgement of mind-body interaction is consistent with the general causal principle(s) formulated in the Third Meditation, and what is the significance in this context of Descartes's statements about physical factors (objects of perception, states of the human brain) as occasions or signs for the mind.

This article analyses the body of English-speaking historico-philosophical writings about Descartes's conception of mind-body interaction ${ }^{1}$ in order to elucidate the main recently debated issues concerned with the coherence between substance dualism, interactionism, and the theory of causality formulated in the Third Meditation, and to ascertain the most plausible ways how Descartes's relevant statements can be seen to agree. The article belongs to the genre of analytic history of philosophy, which "is by its nature focused on terms, theses, and

(C) Д. Сепетій, 2021

${ }^{1}$ In Ukrainian philosophical community, there is a growing interest in this branch of Cartesian scholarship, which manifested itself in the series of recent academic publications ([Bodnarchuk, Sen' 2014], [Laktionova 2015], [Sepetyi 2017; 2018a; 2018b; 2019], [Khoma 2019]). 
arguments", "looks for clarity and distinctness in definitions, and validity and soundness in reasoning” [Nadler 2005: 202], and is primarily engaged with rational reconstructions [Rorty 1984; Beaney 2013; 2019], "the process of identifying the presumably coherent and welljustified system of philosophical commitments that are inherent to a philosopher's works" [Lapointe and Pincock 2017: 3].

\section{The inventory of objections}

The main objections against Descartes's conception of mind-body interaction can be divided into two groups:

1) general objections to the possibility of interaction between physical and non-physical;

2) specific objections that appeal to the alleged contradiction between mind-body interaction and the causal principle(s) formulated in the Third Meditation.

Prima facie, the general objections seem to be supported by Descartes's statements in The Principles of Philosophy, where he argues against the dominant Aristotelian-Scholastic theory that the movements of physical bodies are caused by their substantial forms and real qualities. The argument is that these forms and qualities are believed to be by their nature something different from the spatial properties of bodies (including movements), and it is impossible to understand how the properties of entirely different natures can cause one another. It seems that if the same reasoning is applied to the interaction between mind and body (which, according to Descartes, are substances of entirely different natures), then we must deny their interaction.

The objections that appeal to the causal principle(s) formulated in the Third Meditation are two:

- Descartes is committed to the principle of causal hierarchy, according to which something that has a lower status of being (has a lower «degree of reality») cannot cause something that has a higher status of being (has a greater «degree of reality»). Because bodies (physical reality) have a lower status than minds, a body cannot cause states of a mind, such as those of sensations and perceptions. (From this point of view, the causation in the opposite direction, from mind to body - that is, the powers of volitional mental states to cause motions of the body and thus to control behaviour - is not problematic.)

- Descartes upheld the containment principle of causality, according to which all there is in the effect must be contained, "formally or eminently», in the cause. However, Descartes's theory that mind and body have entirely different natures makes it impossible for physical states to contain anything mental and vice versa; hence, no causation between them is possible.

\section{Neutralizing the general objections}

From Descartes's times to ours, the view that physical processes cannot be causally affected by something non-physical was, and remains, very influential. However, Descartes and a number of later philosophers (see, for example, [Beloff 1994: 516-517], [Popper, 1953: 107], [Popper, 1974: 255], [Chalmers 1996: 170]) explained that there is not much force in that objection. In recent Cartesian scholarship, Robert Richardson argued forcefully and at length that the problem of mind-body interaction is not so difficult for Descartes's philosophy as is usually believed, and it is solved in the same way in which contemporary science solves the problem of fundamental physical interactions - by acknowledging the existence of fundamental causal laws of nature as a fundamental fact about reality that does not require further explanation and cannot be explained. This solution is suggested both by the contemporary scientific treatment of causality and by a number of Descartes’s statements [Richardson 1982]. 
So, in a letter to Arnauld (July 29, 1648), Descartes wrote that the mind's capability to move the body «is one of those self-evident things which we only make obscure when we try to explain them in terms of other things» (AT V, 222: 15-20 / CSMK, 358). ${ }^{2}$ In a letter to Clerselier (January 12, 1646), Descartes characterized the principle to which his opponents appeal, «that if the soul and the body are two substances of diverse nature, that prevents them from being capable of acting on one another», as «a false supposition that can by no manner of means be proved» (AT IX-2, 213 / HR II, 132). Even more telling was Descartes's reply (May 21, 1643) to Princess Elizabeth's objection against the interaction of non-physical mind and physical body. The objection was based on the theory of causality as push, ${ }^{3}$ and Descartes explained that it commits the mistake of applying one of the primitive notions (the notions that «are as it were the patterns on the basis of which we form all our other conceptions»), that of extension, outside its proper domain:

«we go wrong if we ... try to use our imagination ... to conceive the way in which the soul moves the body by conceiving the way in which one body is moved by another» (AT III, 666: 2-15 / CSMK, 218).

So Richardson's conclusion is that for Descartes, physical and psychophysical interactions «are two fundamental and irreducible forms of causal interaction», and because the fundamental and irreducible cannot be explained in terms of something else, «there can be no sense given to the question of how mind acts on body» [Richardson 1982: 26].

I think that these explanations provide good reasons to reject the view that mind-body interaction is a difficult problem for Cartesian dualism merely because it holds that mind and body are substances with entirely different natures.

\section{The treatment of the possibility of interaction between things of different natures in The Principles of Philosophy}

In The Principles, Descartes makes a statement that can be taken for the denial of the possibility of causation between things of different natures. ${ }^{4}$ The statement relates to substantial forms and real qualities, which in the Aristotelian-Scholastic tradition were taken to be active principles in bodies (along with passive matter) that cause their motions. Descartes was an opponent of this view; he argued that the motions of things should be explained in terms of causes of the same kind (modes of the attribute of extension), and that substantial

${ }^{2}$ Here and forthwith, references to the texts of Descartes and his correspondents are made to the classical French/Latin edition by Adam and Tannery [Descartes 1996], abbreviated as AT, and the English editions: Volumes I and II of The Philosophical Writings of Descartes, transl. by J. Cottingham, R. Stoothoff, and D. Murdoch [Descartes 1985], abbreviated as CSM; Volume III of The Philosophical Writings of Descartes, transl. by J. Cottingham, R. Stoothoff, D. Murdoch, and A. Kenny [Descartes 1991], abbreviated as CSMK; The Philosophical Works of Descartes, transl. by E. Haldane and G. R. T. Ross [Descartes 1931], abbreviated as HR; The Correspondence Between Princess Elisabeth and René Descartes, ed. and trans. by L. Shapiro [Elisabeth and Descartes 2007], abbreviated as LS. The abbreviation is followed by a blank, the volume (if any, in Roman numerals), a comma, and the page number. For AT, this is followed by a colon and the numbers of the rows.

${ }^{3}$ Elizabeth wrote that «it seems that all determination of movement happens through the impulsion of the thing moved, by the manner in which it is pushed by that which moves it, or else by the particular qualities and shape of the surface of the latter» (AT III, 661: 11-15 / LS, 62).

${ }^{4}$ Daisie Radner adduces this statement in support of her view that Descartes held the principle of the preexistence (containment) in the cause of all that is in the effect (see section 4 for details) [Radner 1971: 167]. However, it is obvious that in the statement itself, this principle is not formulated, and the statement can support the principle only indirectly, if it asserts the impossibility of the interaction between things with different natures, and if the reason for this assertion is the preexistence principle. In this section, we check the first of these ifs. 
forms and real qualities are fictions that correspond to nothing really existent. Descartes explained this as follows:

«we understand $\{$ French concevoir $\}$ very well how the different size, shape and motion of the particles of one body can produce various local motions in another body. But there is no way of understanding \{French entendre \}ow these same attributes (size, shape and motion) can produce something else whose nature is quite different from their own - like the substantial forms and real qualities which many <philosophers> suppose to inhere in things; and we cannot understand how these qualities or forms could have the power subsequently to produce local motions in other bodies.» (AT IX-2, 317 / CSM I, 285)

So, according to Descartes, because substantial forms and real qualities are taken to be something of entirely different nature than such properties as size, form, and motion, we cannot understand how the former can cause the latter. If so, then Descartes would have to admit the same for the states of soul and body, and deny their capacity to act one upon another!

However, this conclusion is arguably mistaken, because our inability to understand something does not entail its nonexistence, and Descartes did not hold as a general principle the view that nothing exists beyond our capacity of understanding. (After all, he believed in the existence of God, whose properties are, at least to a large extent, beyond this capacity.) In particular, in the case of substantial forms and real qualities, Descartes did not infer that substantial forms and real qualities do not exist or cannot causally interact with the spatial properties of bodies directly from our failure to understand how this interaction can be effectuated. Although he eventually rejected the existence of substantial forms and real qualities, his reasons for this were more complicated. Descartes argued that there are no rational grounds for assuming the existence of substantial forms and real qualities, and therefore it is unreasonable to believe in their existence (although it is impossible to prove their non-existence). On the one hand, they are not something directly or experientially known (neither something manifest by the natural light of reason, nor something revealed in experience); the concepts of substantial forms and real qualities are theoretical constructs that were introduced by Aristotle and adopted by scholastics for the purpose of explaining the behaviour of things. On the other hand, Descartes argued that in fact they did not perform the explanatory function for which they were introduced - at least, insofar as we have another, much better and understandable explanation in terms of spatial properties. (This is the context to which the quoted fragment belongs.) If so, then the ideas of substantial forms and real qualities are entirely superfluous. This approach to the problem of substantial forms is succinctly and clearly formulated in Descartes’s letter to Regius (January, 1642):

«... up to now we have certainly not rejected them absolutely; we merely claim that we do not need them in order to explain the causes of natural things. ... Now in such matters, saying that one does not wish to make use of these entities is almost the same as saying one will not accept them; indeed, they are accepted by others only because they are thought necessary to explain the causes of natural effects. So we will be ready enough to confess that we do wholly reject them. ... They were introduced by philosophers solely to account for the proper actions of natural things ... But no natural action at all can be explained by these substantial forms ... So these forms are not to be introduced to explain the causes of natural actions.» (AT III, 500: 9-20, 506: 5-15 / CSMK, 207, 208-209) 
In the case of body and soul, the situation, on Descartes's view, is quite different, because the existence of bodily and mental states and their interaction are perfectly obvious and indubitable, and Descartes's arguments (especially, in Meditations) had proven that they belong to substances with entirely different natures, mind (soul, res cogitans) and body (res extensa). Accordingly, the mind (soul) and its mental states are not theoretical constructs that have been introduced for certain explanatory purposes and should be abandoned if other, better explanatory means are invented. They are «the hard data» that should be acknowledged; they cannot be declared non-existent. Likewise, on Descartes's view, it is an undeniable obvious fact that sensations and perceptions (which are states of the soul) are caused by certain states of the body, and that volitions (which are states of the soul) can cause certain movements of the body (behaviour). Descartes believed that the Aristotelian-Scholastic concepts of substantial forms and real qualities are products of the mistaken attribution to other things of what pertains only to the human soul in its relation to the human body (AT VII, 441: 23-443: 4 / CSM II, 297-298; AT III, 667: 4-668: 4 / CSMK, 219), and in this sense, one can speak of soul (mind) as the only true substantial form (letter to Regius, January, 1642 (AT III, 505: 17-18 / CSMK, 208)).

This explanation can be supplemented with another, based on the distinction (made by Mark Bedau) of two principally different meanings in which one can speak of the inconceivability of mind-body interaction:

«(T) It is inconceivable that distinct kinds of substance interact.»

and

«(H) It is inconceivable how distinct kinds of substance interact.»

The inconceivability-that- $X$ involves the judgement that $\mathrm{X}$ is impossible. The inconceivability-how- $X$ means only that our minds are incapable of conceiving the way in which $\mathrm{X}$ is effectuated. Bedau plausibly suggests that Descartes took it to be conceivable (and, moreover, obvious) that the mind and the body interact, although he took it to be inconceivable how they interact [Bedau 1986: 485-486].

\section{Cartesian interaction and ontological hierarchy}

The claim that Descartes was committed to the causal principle according to which something that has a lower status of being (a smaller «degree of reality») cannot cause something that has a higher status of being (a «greater degree of reality») is based on his statements in the Third Meditation:

«Now it is manifest by the natural light that there must be at least as much $<$ reality $>$ in the efficient and total cause as in the effect of that cause. For where, I ask, could the effect get its reality from, if not from the cause? And how could the cause give it to the effect unless it possessed it? It follows from this both that something cannot arise from nothing, and also that what is more perfect - that is, contains in itself more reality - cannot arise from what is less perfect.» (AT VII, 40: 21-41: 1 / CSM II, 28)

From now on, I will refer to the principle that the cause must have no less reality that the effect as the Hierarchy Principle.

How is this principle relevant to the interaction of soul and body? Daisy Radner suggests that Descartes's views were similar to the views of Saint Augustine, who believed that the soul has a higher status of being than the body, and therefore the soul can (and does) act upon the body (and so rules human action) but the body cannot (and so does not) act upon the soul [Radner 1971: 159-160]. If Descartes also took the soul to be located on a higher level of the 
ontological hierarchy than the body, and given the Hierarchy Principle of causality, he should hold that bodily states (such as tissue damage or retinal excitation or any physical processes in the brain) cannot cause mental states of the soul (such as pain or visual perceptions).

We can try two ways of neutralizing this objection.

First, it can be pointed out that Descartes never stated that the soul has a higher degree of reality than the body. In the context in which Descartes stated the Hierarchy Principle (the Third Meditation), he explicitly distinguished only three levels of reality: 1) the infinite substance, that is, God, has the greatest degree of reality; 2) finite substances, that is, souls and bodies, have a degree of reality lower than that of God; 3) modes of finite substances have an even lower degree of reality (AT VII, 40: 12-20 / CSM II, 28). Tad Schmaltz calls this «the simple ontological hierarchy» [Schmaltz 2008: 53]. If souls and bodies are on the same (second) level of the hierarchy, then the Hierarchy Principle does not prohibit the causal influence of a body on a soul.

However, there is an indirect textual evidence that Descartes's view was that the soul is higher in the ontological hierarchy than the body. In the Six Meditation, Descartes considers the possible origins of my ideas of bodies (bodies' existence not established as yet): these ideas may be produced either by the bodies themselves, or by God, or by «some creature more noble than a body in which case it will contain eminently whatever is to be found in the ideas» (AT VII, 79: 18-22 / CSM II, 55). It seems that in Descartes's philosophy, eminent containment presupposes a higher level of the ontological hierarchy, and in this statement «more noble» is connected with eminent containment, and hence with a higher level of the ontological hierarchy. In much later text, a letter to Princess Elizabeth, Descartes wrote that the soul «is much nobler than the body» (AT IV, 292: 6-7 / CSMK, 265). If we connect all this together, it seems that we should conclude that for Descartes, since the soul is nobler than the body, it stands on a higher level of the ontological hierarchy. However, perhaps this indirect evidence is to be discounted, taking into account different contexts of the two statements and a considerable passage of time between Meditations (completed by April 1640) and the letter (September 1645).

It may seem that even if the soul stands on a higher level of the ontological hierarchy than the body, Descartes made explanation that reconciles this with the body-to-mind causality. Namely, Descartes stated the following two theses:

1) the cause can contain «formally or eminently» what the effect contains «objectively», where the adverb «formally» means what we would call the real existence of a thing, and the adverb «objectively» means the mental representation of a thing, its «containment in an idea» ${ }^{5}$; and

2) «The nature of an idea is such that of itself it requires no formal reality except what it derives from my thought, of which it is a mode» (AT VII, 41: 17-20 / CSM II, 28).

${ }^{5}$ In Descartes's philosophy, the term «objective reality» has an entirely different meaning from that typical for its present-day use. What we now usually mean by «objective reality» is Descartes's «formal reality». The Stanford Encyclopedia of Philosophy explains Descartes's meanings as follows:

«The formal reality of a thing is the kind of reality the thing possesses in virtue of its being an actual or an existent thing (AT VII 41-42, 102-4; CSM II 28-29, 74-5). ... The objective reality of a thing is the kind of reality a thing possesses in virtue of its being a representation of something (ibid.).... Descartes says that ideas possess objective reality by their very nature. Equally importantly, ideas are the only items in his ontology that possess both formal and objective reality (AT VII 42; CSM II 29).» [Smith 2017]

Descartes himself defined «objective reality of an idea» as «the being of the thing which is represented by an idea, insofar as this exists in the idea» (AT VII, 161: 4-7; CSM II, 113). 
Taken together, these two theses entail that bodies can cause some features of the soul's states, viz., their representational content, even if the soul has a higher ontological status (which is a matter of its «formal reality»).

However, there arises a serious problem if we consider the causation of sensuous and perceptual mental states not by the things (bodies) that are represented in these states (the tree that I see, for example) but by the brain states that are the direct physical causes of these mental sates. These brain states are not represented («objectively contained») in the sensations and perceptions they cause. If so, the brain states contain, formally or eminently, nothing of sensations and perceptions (even what exists it the latter «objectively»); hence, brain states cannot cause sensations and perceptions.

Probably, a more promising way to reconcile the Hierarchy Principle with mind-body interaction can begin with pointing out that although the Principle says that in the efficient and total cause there must be at least as much reality as in the effect, it does not prohibit other causes (incomplete, or not qualifying as «efficient», in Descartes's vocabulary) that have less reality. Descartes has repeatedly expressed the view that some motions in the brain serve as natural «signs» or «occasions» for the soul to form or conceive sensuous (perceptual) ideas (AT XI, 4: 3-17 / CSM I, 81; AT XI, 144: 3-4, 9-13 / CSM I, 103; AT XI, 149: 9-10 / HR, 46; AT VIII-2, 359: 1-5, 12-15 / CSM 304). Such statements suggest that Descartes believed that the soul itself was the efficient cause of its feelings and perceptions. However, in a certain pretty clear sense, the bodily (brain) states are also causes: without them, the soul would not have the corresponding sensuous (perceptual) states. Margaret Wilson drew attention to the fact that in a number of other statements Descartes describes the relations of soul and body involved in sensations and perceptions in expressly causal terms: brain states affect (Latin afficiere) soul (AT VIII-I, 316: 6-8; AT VII, 87: 10, 20-21), make (French faire) soul to have a sensation (AT XI, 144: 27-28; AT XI, 145: 26)), evoke (Latin inferre) (AT VII, 87: 23), excite (French excite) (AT IV, 326: 23)), produce (Latin producendi) (AT VII, 79: 11), cause (French causer, Latin efficiendi) (AT VI, 334: 20-25; AT III, 665: 24; AT VII, 79: 11) sensations in the soul [Wilson 1991: 295-296]. The bodily states that cause, or on the occasion of which the soul forms, the corresponding mental states are part of the total cause of these mental states (together with the capacity of the soul to generate such states on an appropriate occasion). ${ }^{6}$

It is also worthwhile to consider the explanation advanced by Stephen Nadler, who argued that in Descartes's philosophy, as well as in works of some of his important followers, two distinct models of causality co-exist and play important roles: along with the model of efficient causality, which was «standard» for that time, there was another, «non-standard» model, of «occasional causality» (it is important not to confuse it with occasionalism). Later, this model (to a large extent, due to David Hume's arguments) entirely supplanted the model of efficient causality [Nadler 1994]. On Nadler's construal, Descartes's causal statements in

${ }^{6}$ Wilson also explains that Descartes described brain states as occasions or signs for the soul not because he thought that their causal efficacy is problematic, but in order to «establish the point, essential to his mechanistic approach to physical phenomena, that the state of the brain that leads up to perceptual experience need not "resemble" the perceptual experience itself», that in a sense, «it is an entirely arbitrary matter which brain state is connected to which sensory idea» [Wilson 1991: 296] (just as linguistic signs need not be in any way similar either to what they signify or to the thoughts they evoke; for example, the typed word «table» is not like a table; neither is it similar to the mental state of thinking about a table; the meaning of a word is just an arbitrary human institution). 
the Third Meditation pertain to efficient causality, whereas his view that soul and body causally interact implies occasional causality.

\section{Cartesian interaction and the Containment Principle}

Dasie Radner ([Radner 1971; 1985]), Janett Broughton [Broughton 1986], and Jeffrey Gorham ([Gorham 2002; 2003]) argue that Descartes held even more restrictive causal principle - that the cause must contain all there is in the effect. Let us designate this as the Containment Principle. The claim that Descartes held this principle is supported by some of his explanations in the Third Meditation, as well as in the Response to the Second Objections:

«A stone, for example, which previously did not exist, cannot begin to exist unless it is produced by something which contains, either formally or eminently everything to be found in the stone ...» (AT VII, 41: 4-8 / CSM II, 28)

«The fact that "there is nothing in the effect which was not previously present in the cause, either in a similar or in a higher form” is a primary notion which is as clear as any that we have; it is just the same as the common notion "Nothing comes from nothing." For if we admit that there is something in the effect that was not previously present in the cause, we shall also have to admit that this something was produced by nothing.» (AT VII, 135: 11-16 / CSM II, 97)

However, Descartes's view that mind and body have entirely different natures seems to entail that bodily causes cannot contain anything of mental effects and vice versa. Therefore, mind-body interaction should be impossible.

There are several ways how this apparent incoherence can be merely apparent rather than genuine.

1) A number of Cartesian scholars (see, for example, [Loeb 1981], [Bedau 1986], [De Rosa 2013]) defend the view that Descartes, in statements that read like the Containment Principle, did really mean only the Hierarchy Principle. ${ }^{7}$ This view is supported by two important considerations.

First, it seems that Descartes himself did not distinguish between the Hierarchy Principle and the Containment Principle. He writes as if he means one principle (let us designate it as «the Principle»), sometimes describing it so that it reads like the Hierarchy Principle, and sometimes - so that it reads like the Containment Principle. One kind of description sometimes directly follows another; for example, the fragment about a stone (quoted above), which looks involving the Containment Principle, is followed by the explanation that looks involving only the Hierarchy Principle:

«similarly, heat cannot be produced in an object which was not previously hot, except by something of at least the same order < degree or kind $>$ of perfection as heat, and so on. But it is also true that the idea of heat, or of a stone, cannot exist in me unless it is put there by some cause which contains at least as much reality as I conceive to be in the heat or in the stone.» (AT VII, 41: 8-14 / CSM II, 28)

Second, for those purposes for which Descartes used the Principle, it is enough that it were the Hierarchy Principle. A stronger principle (the Containment Principle) is not needed. So, whether Descartes held it or not, he need not be committed to it. Nothing in Descartes

\footnotetext{
${ }^{7}$ As Bedau points out, in the largest part of the secondary literature this view is accepted even without discussing the alternative defended by Radner, Broughton, and Gorham [Bedau 1986: 498].
} 
philosophical system hangs on the Containment Principle, whereas very much (Descartes's proof of God's existence) hangs on the Hierarchy Principle.

On the other hand, Descartes's statements above seem to be pretty clear and unequivocal in saying that the cause must contains (formally or eminently) everything to be found in the effect (that «there is nothing in the effect which was not previously present in the cause»). So the literal reading supports the construal defended by Radner, Broughton, and Gorham.

2) If Descartes really held the Containment Principle, can this be reconciled with mindbody interaction?

Robert Richardson suggests that this can be done on the basis of Descartes's explanations in the Third Meditation that involve a distinction between formal reality and objective reality, and assert that the cause can contain formally or eminently what the effect contains $o b$ jectively: «it is clear that Descartes does not require that the mode of existence be the same» [Richardson 1985: 223-224].

Descartes believed - and grounded on this his proof of God's existence in the Third Meditation - that because we have some idea, what is contained in that idea «objectively» (that is, what the idea represents) must exist in its complete efficient cause «formally or eminently»:

«... The nature of an idea is such that of itself it requires no formal reality except what it derives from my thought, of which it is a mode. But in order for a given idea to contain such and such objective reality, it must surely derive it from some cause which contains at least as much formal reality as there is objective reality in the idea. For if we suppose that an idea contains something which was not in its cause, it must have got this from nothing; yet the mode of being by which a thing exists objectively <or representatively> in the intellect by way of an idea, imperfect though it may be, is certainly not nothing, and so it cannot come from nothing.» (AT VII, 41: 17-29 / CSM II, 28-29)

With respect to sensations and perceptions, this can mean that physical states and processes can contribute to their causation, so that sensations and perceptions can represent (contain «objectively») these states and processes. For example, a sensation of pain may represent some kind of bodily injury, a visual perception may represent a thing located in the field of my vision, and so on. In these cases, these physical states or things exist «formally» in the world of extended things and «objectively» in my sensations and perceptions. However, it is clear that physical states on their own are insufficient to produce the corresponding sensations or perceptions; in order for the latter to arise, there has to be the mind in which they arise, and their formal reality (which may consist in their specific subjective character, how it feels) is due to the capacities (dispositions) of the mind.

This allows to answer Radner's objection that 1 ) even if the physical states of the body (brain) are not the complete cause of the sensory-perceptual states of the associated mind, the Containment Principle requires that they contain at least something of the «stuff» of those sensuous (perceptual) states of the mind, and 2) this is impossible if, as Descartes holds, mind and body have entirely different natures (extended bodies and their movements contain nothing of thinking) [Radner 1985: 43]. The answer can be as follows. Because Descartes considered sensations and perceptions as modes of thinking, we can say about their nature the same thing that Descartes said about the nature of an idea: it «requires no formal reality except what it derives from my thought, of which it is a mode» (AT VII, 41: 17-20 / CSM II, 28). So all that sensuous and perceptual mental states receive from physical bodies and their motions is objective (representative) reality: whatever sensations (perceptions) contain 
objectively (insofar as they represent certain states of affairs in physical reality), physical reality contains formally.

However, there are two problems with this interpretation.

First, we know, and Descartes knew, that the direct physical causes of sensuous (perceptual) mental states are not the physical bodies (or states, or processes) that these sensations (perceptions) represent but some physical processes in the brain, which are not even known to the mind. So the question arises: how can these physical brain states cause sensations and perceptions, given that they do not formally or eminently contain what is objectively contained in the sensations (perceptions)?

Second, how causation in the opposite direction (from volitional mental states to physical processes in the brain and the corresponding behaviour) is possible? Can it be that Descartes's theory of causality allowed «the conversion of reality» not only from the formal to the objective (body-to-mind causality) but also from the objective to the formal (mind-to-body causality)? There is no textual evidence for this. Descartes's statement was that the cause must contain formally or eminently all there is in its effect; there is no provision for the possibility that the cause contains neither formally nor eminently but objectively all there is in its effect.

Also, on Descartes' view, objective containment is not eminent containment; on the contrary, he is ready to admit that the «objective reality» of a thing is less perfect than its «formal reality»: «the mode of being by which a thing exists objectively <or representatively> in the intellect by way of an idea, imperfect though it may be, is certainly not nothing» (AT VII, 41: 26-29 / CSM II, 29). That the objective reality of a thing is less perfect than its formal reality is important for Descartes's proof of God's existence: the proof moves from an effect, which is the objective reality of God in my mind, to its cause, which is the formal reality of God, that is, God Himself.

Besides, even if «the conversion of reality» from formal to objective were allowable, there would be a problem of the kind we pointed out three paragraphs above («First, ...») for the opposite causal direction. We know, and Descartes knew, that volitional mental states cause the physical states (or events) they represent - certain behaviour and its results - not directly but through the mediation of physical states and processes (primarily, in the brain) they do not represent. The volitional states directly cause some physical brain states, although they do not represent (contain «objectively») these states. (Such brain states normally are not even known to the mind.) Nor do they contain these states formally or eminently.

The more promising ways to reconcile the Containment Principle with mind-body interaction involve the acknowledgement that the content of our ideas about the physical world is not communicated by physical causes but derives from some other sources, whereas the relevant physical processes in the brain serve as an occasion or sign. As for the sources of the content of our sensations and perceptions, there are two direct candidates.

1) On Malebranche's theory of occasionalism, the direct cause of all our sensations, perceptions, etc. is God; He produces in human minds all sensations and perceptions on occasions of specific physical events (instantiations of specific brain states).

2) Descartes's own view (supported by many his statements) seems to be that the content of our sensations and perceptions (the way they represent the physical world) is to be accounted in terms of the «innate ideas» of human minds, which are sort of actualized on the relevant physical occasions. The most direct Descartes's statement to this point is found in his «Comments on a Certain Broadsheet» (1648). There, Descartes directly says that the ideas of movements, forms, and colours, sounds, etc. are innate (AT VIII-2, 359: 11-14 / CSM I, 304). As for more specific ideas that represent concrete physical objects and events 
on the relevant occasions, it is clear that they are some modifications and combinations of those basic innate ideas. So, the relevant states of the brain serve as occasions or natural signs for the mind to actualize the corresponding modifications and combinations of its own innate ideas, or "give the mind occasion to form these ideas by means of the faculty innate to it» (AT VIII-2, 359: 1-5 / CSM I, 304). ${ }^{8}$

It seems natural to see this, as Stephen Nadler proposes, in terms of the model of occasional causality [Nadler 1994: 45-47]: the relevant physical states of the brain are occasional rather than efficient causes of sensations and perceptions. Alternatively, they can be considered as efficient but incomplete causes - parts of the total efficient cause, which includes also other components, such as the mind's own properties and dispositions, the psychophysical laws of interaction (the Natural Institution, in terms of [Wilson 1978]), the substantial union of an individual mind with an individual body. (Besides, eventually the complete efficient cause is God, who contains eminently all His creation.)

The point about incomplete causes works as well in the causal direction from mind to body (whereas the model of occasional causality seems inapplicable for this direction). The efficient complete cause includes (1) volitional mental states, (2) the capacity of bodies, including minute particles in the brain («animal spirits»), to move, and (3) the laws of nature that connect (1) and (2). Given (1), (2), and (3), the effect (motions) follows from the complete cause, and so is contained in it.

Another way to deal with causation in the mind-to-body direction is to suppose that on Descartes's view, human souls eminently contain all there is in physical motions of bodies. This may look out of line with the Cartesian doctrine that souls and bodies have entirely different nature; however, it is not clear whether there is a real conflict, because it is generally very unclear what Descartes's notion of eminent containment involves. What is clear is that for Descartes, God eminently contains all His creation; however, it seems that God's nature is entirely different from the nature of physical reality. If so, then the difference of natures of $\mathrm{A}$ and $\mathrm{B}$ does not entail the impossibility that A eminently contains modes of B.

In recent debates, Cartesian scholars made several points about Descartes's notion of eminent containment ([O’Neill 1987], [Schmaltz 2008: 67-71]) that are relevant to our discussion. First, for A to eminently contain B, or modes of B, A should stand higher than B in the ontological hierarchy. With soul and body, this requirement is likely to be satisfied, given Descartes's statement in the letter to Elisabeth that the soul «is much nobler than the body» (AT IV, 292: 6-7 / CSMK, 265). Second, in the case of God, His eminent containment of all His creation can consist merely in His power to produce it. However, the case with souls and bodily motions seems to be different: human souls generally have no power to produce at will bodies and bodily motions, except in cases of human behaviour. So, for souls to contain eminently bodily motions, the requirement for eminent containment should be weaker than having powers to produce bodily motions at will. One relevant suggestion, made by Tad

${ }^{8}$ Nevertheless, the faculty of mind to form such ideas on the relevant occasions is a passive faculty, in the sense that «it presupposes no intellectual act on my part, and the ideas in question are produced without my cooperation and often even against my will» (AT VII, 79: 12-14 / CSM II, 55). Descartes held this view in the Meditations, and he held it in his last book, The Passions of the Soul; so it is unlikely that he did not held it in between, when writing Comments. Admittedly, there seems to be some change between the Meditations and the Comments: in the Meditations, Descartes described the faculty at issue as «a faculty for receiving and recognizing the ideas of sensible objects» (AT VII, 79: 7-9 / CSM II, 55); this description is in tension with the statements in the Comments. 
Schmaltz [Schmaltz 2008: 67-71], is that for Descartes, the requirement for eminent containment is that A should have power to produce at least the objective reality of $\mathrm{B}$. If this is the case, then the soul's power to conceive at will of physical motions, plus its higher place in the ontological hierarchy is enough for the soul to eminently contain physical motions. It may seem that Schmaltz's suggestion makes eminent containment, which is higher than formal containment, too close to objective containment, which is lower than formal containment; however, the difference between the power to produce the objective reality of a thing and the objective reality of a thing may be sufficient to account for the hierarchical difference.

Finally, it is worth remarking that Descartes himself did not bother at all about explaining how mind-body interaction is consistent with the causal principle he formulated in the Third Meditation. I conjecture that his reason for this was that eventually, the total and efficient cause of everything is God, who is omnipotent and surely has it in His power to arrange things so that some events in the world of res extensa evoked some sensuous and perceptual states of some res cogita, and that volitional states of res cogita evoked some movements of some res extensa. The details of this arrangement can be beyond our comprehension, but the fact that there is such an arrangement is perfectly clear.

\section{СПИСОК ЛІТЕРАТУРИ}

Боднарчук, Л., \& Сень, А. (2014). Котингемова концепція тріалізму Декарта й сучасні дискуciï. Sententiae, 30(1), 196-209. https://doi.org/10.22240/sent30.01.196

Лактіонова, А. (2015). «Cogito ergo sum» і філософія дії. Sententiae, 32(1), 88-99. https://doi.org/10.22240/sent32.01.088

Сепетий, Д. (2017). Психофізичний дуалізм Декарта у сучасній ретроспективі. Філософська думка, (3), 64-73.

Сепетий, Д. (2018а). Співвідношення понять субстанційного союзу і взаємодії душі й тіла у філософії Декарта. Sententiae, 37(1), 136-152. https://doi.org/10.22240/sent37.01.136

Сепетий, Д. (2018b). Чи був Декарт субстанційним дуалістом? Актуальні проблеми духовності, (19), 36-63. https://doi.org/10.31812/apd.v0i19.2069

Хома, О. (2019). Сучасне глобальне декартознавство. Nadler, S. et al (2019). The Oxford Handbook of Descartes and Cartesianism. Oxford: Oxford UP. Sententiae, 38(2), 112-115. https://doi.org/10.22240/sent38.02.112

Beaney, M. (2013). Analytic Philosophy and History of Philosophy: The Development of the Idea of Rational Reconstruction. In E. Reck (Ed.), The Historical Turn in Analytic Philosophy (pp. 231-260). London: Palgrave Macmillan.

Beaney, M. (2019). Developments and Debates in the Historiography of Philosophy. In K. Becker (Ed.), The Cambridge History of Philosophy, 1945-2015 (pp. 725-758). Cambridge: Cambridge University Press. https://doi.org/10.1017/9781316779651.058

Bedau, M. (1986). Cartesian Interaction. Midwest Studies in Philosophy, 10, 483-502. https://doi.org/10.1111/j.1475-4975.1987.tb00552.x

Beloff, J. (1994). The Mind-Body Problem. The Journal of Scientific Exploration, 8(4), 509-522.

Broughton, J. (1986). Adequate Causes and Natural Change in Descartes' Philosophy. In A. Donagan, A. N. Perovich, Jr., \& M. V Wedin (Eds.), Human Nature and Natural Knowledge (pp. 107127). Dordrecht: D. Reidel Publishing Company. https://doi.org/10.1007/978-94-009-5349-9_6 Brown, D. (2019). The Metaphysics of Cartesian Persons. In M. Reuter, \& F. Svensson (Eds.), Mindy, Body, and Morality: New Perspectives on Descartes and Spinoza (pp. 17-36). London, New York: Routledge. https://doi.org/10.4324/9781351202831-2 
Chalmers, D. (1996). The Conscious Mind. New York, Oxford: Oxford University Press.

Christofidou, A. (2019). Descartes: A Metaphysical Solution to the Mind-Body Relation and the Intellect's Clear and Distinct Conception of the Union. Philosophy, 94(1), 87-114. https://doi.org/10.1017/S0031819118000323

De Rosa, R. (2013). Descartes' Causal Principle and the Case of Body-to-Mind Causation. Canadian Journal of Philosophy 43(4), 438-459. https://doi.org/10.1080/00455091.2013.847347

Descartes, R. (1931). The Philosophical Works of Descartes. (E. Haldane, \& G. R. T. Ross, Transl.) Cambridge: Cambridge University Press, 1931.

Descartes, R. (1985). The Philosophical Writings of Descartes. (J. Cottingham, R. Stoothoff, \& D. Murdoch, Transl.). Volumes I-II. Cambridge: Cambridge University Press. https://doi.org/10.1017/CBO9780511818998

Descartes, R. (1991). The Philosophical Writings of Descartes. (J. Cottingham, R. Stoothoff, D. Murdoch, \& A. Kenny, Transl.). Vol. III. Cambridge: Cambridge University Press. https://doi.org/10.1017/CBO9781107340824

Descartes, R. (1996). Euvres complètes in 11 vol. (Ch. Adam, \& P. Tannery, Eds.). Paris: Vrin.

Elisebeth of Bohemia, Descartes, R. (2007). The Correspondence Between Princess Elisabeth and René Descartes (L. Shapiro, Ed. \& Trans.). Chicago and London: University of Chicago Press. https://doi.org/10.7208/chicago/9780226204444.001.0001

Gorham, G. (2002). Descartes on the Innateness of All Ideas. Canadian Journal of Philosophy, 32(3), 355-388. https://doi.org/10.1080/00455091.2002.10716523

Gorham, G. (2003). Descartes's Dilemma of Eminent Containment. Dialogue, 42(1), 3-26. https://doi.org/10.1017/S0012217300004182

Hoffman, P. (2009). Essays on Descartes. New York, Oxford: Oxford University Press.

Lapointe, S., \& Pincock, C. (2017). Introduction. In S. Lapointe, \& C. Pincock (Eds.), Innovations in the History of Analytical Philosophy (pp. 1-23). London: Palgrave Macmillan. https://doi.org/10.1057/978-1-137-40808-2_1

Loeb, L. (1981). From Descartes to Hume. Ithaca: Cornell University Press.

O’Neill, E. (1987). Mind-Body Interaction and Metaphysical Consistency: A Defense of Descartes. Journal of the History of Philosophy, 25(2), 227-245. https://doi.org/10.1353/hph.1987.0026

Nadler, S. (1994). Descartes and Occasional Causation. British Journal for the History of Philosophy, 2(1), 35-54. https://doi.org/10.1080/09608789408570891

Nadler, S. (2005). Hope, Fear, and the Politics of Immortality. In T. Sorell. \& G. Rogers (Eds.), Analytic Philosophy and History of Philosophy (pp. 201-217). New York, Oxford: Oxford University Press.

Popper, K. (1953). Language and the Body-Mind Problem. Proceedings of the 11th International Congress of Philosophy, 7, 101-107. https://doi.org/10.5840/wcp1119537216

Popper, K. (1974). Objective Knowledge: Evolutionary Approach. New York, Oxford: Oxford University Press.

Radner, D. (1971). Descartes' Notion of the Union of Mind and Body. Journal of the History of Philosophy, 9(2), 159-170. https://doi.org/10.1353/hph.2008.1109

Radner, D. (1985). Is There a Problem of Cartesian Interaction? Journal of the History of Philosophy, 23(1), 35-49. https://doi.org/10.1353/hph.1985.0012

Richardson, R. C. (1982). The «Scandal» of Cartesian Interactionism. Mind, 91(361), 20-37. https://doi.org/10.1093/mind/XCI.361.20

Richardson, R. C. (1985). Union and Interaction of Body and Soul. Journal of the History of Philosophy, 23(2), 221-226. https://doi.org/10.1353/hph.1985.0038

Rorty, R. (1984). The historiography of philosophy: four genres. In R. Rorty, J. B. Schneewind, \& Q. Skinner (Eds.), Philosophy in History (pp. 49-75). Cambridge: Cambridge University Press. https://doi.org/10.1017/CBO9780511625534.006

Schmaltz, T. (2008). Descartes on Causation. New York, Oxford: Oxford University Press. https://doi.org/10.1093/acprof:oso/9780195327946.001.0001

Sepetyi, D. (2019). Forty years after: reconsidering the problem of Descartes's Natural Institution theory vs the Coextension theory. Filosofska Dumka, (1), 106-119. 
Smith, K. (2017). Descartes’ Theory of Ideas. Retrieved November 13, 2017 from Stanford Encyclopedia of Philosophy website: https://plato.stanford.edu/entries/descartes-ideas/\#ideasmodes

Wilson, M. (1978). Descartes. London, New York: Routledge.

Wilson, M. (1991). Descartes on the Origin of Sensation. Philosophical Topics, 19(1), 293-323. https://doi.org/10.5840/philtopics199119121

Одержано 18.10.2020

\section{REFERENCES}

Beaney, M. (2013). Analytic Philosophy and History of Philosophy: The Development of the Idea of Rational Reconstruction. In E. Reck (Ed.), The Historical Turn in Analytic Philosophy (pp. 231-260). London: Palgrave Macmillan.

Beaney, M. (2019). Developments and Debates in the Historiography of Philosophy. In K. Becker (Ed.), The Cambridge History of Philosophy, 1945-2015 (pp. 725-758). Cambridge: Cambridge University Press. https://doi.org/10.1017/9781316779651.058

Bedau, M. (1986). Cartesian Interaction. Midwest Studies in Philosophy, 10, 483-502. https://doi.org/10.1111/j.1475-4975.1987.tb00552.x

Beloff, J. (1994). The Mind-Body Problem. The Journal of Scientific Exploration, 8(4), 509-522.

Bodnarchuk, L., \& Sen', A. (2014). Cottingam's Conception of Descrates's Trialism and Modern Discussions. [In Ukrainian]. Sententiae, 30(1), 196-209. https://doi.org/10.22240/sent30.01.196

Broughton, J. (1986). Adequate Causes and Natural Change in Descartes' Philosophy. In A. Donagan, A. N. Perovich, Jr., \& M. V Wedin (Eds.), Human Nature and Natural Knowledge (pp. 107-127). Dordrecht: D. Reidel Publishing Company. https://doi.org/10.1007/978-94-009-5349-9 6

Brown, D. (2019). The Metaphysics of Cartesian Persons. In M. Reuter, \& F. Svensson (Eds.), Mindy, Body, and Morality: New Perspectives on Descartes and Spinoza (pp. 17-36). London, New York: Routledge. https://doi.org/10.4324/9781351202831-2

Chalmers, D. (1996). The Conscious Mind. New York, Oxford: Oxford University Press.

Christofidou, A. (2019). Descartes: A Metaphysical Solution to the Mind-Body Relation and the Intellect's Clear and Distinct Conception of the Union. Philosophy, 94(1), 87-114. https://doi.org/10.1017/S0031819118000323

De Rosa, R. (2013). Descartes' Causal Principle and the Case of Body-to-Mind Causation. Canadian Journal of Philosophy 43(4), 438-459. https://doi.org/10.1080/00455091.2013.847347

Descartes, R. (1931). The Philosophical Works of Descartes. (E. Haldane, \& G. R. T. Ross, Transl.) Cambridge: Cambridge University Press, 1931.

Descartes, R. (1985). The Philosophical Writings of Descartes. (J. Cottingham, R. Stoothoff, \& D. Murdoch, Transl.). Volumes I-II. Cambridge: Cambridge University Press. https://doi.org/10.1017/CBO9780511818998

Descartes, R. (1991). The Philosophical Writings of Descartes. (J. Cottingham, R. Stoothoff, D. Murdoch, \& A. Kenny, Transl.). Vol. III. Cambridge: Cambridge University Press. https://doi.org/10.1017/CBO9781107340824

Descartes, R. (1996). Euvres complètes in 11 vol. (Ch. Adam, \& P. Tannery, Eds.). Paris: Vrin.

Elisebeth of Bohemia, Descartes, R. (2007). The Correspondence Between Princess Elisabeth and René Descartes (L. Shapiro, Ed. \& Trans.). Chicago and London: University of Chicago Press. https://doi.org/10.7208/chicago/9780226204444.001.0001

Gorham, G. (2002). Descartes on the Innateness of All Ideas. Canadian Journal of Philosophy, 32(3), 355-388. https://doi.org/10.1080/00455091.2002.10716523

Gorham, G. (2003). Descartes's Dilemma of Eminent Containment. Dialogue, 42(1), 3-26. https://doi.org/10.1017/S0012217300004182

Hoffman, P. (2009). Essays on Descartes. New York, Oxford: Oxford University Press.

Khoma, O. (2019). Contemporary global Descartes studies. Nadler, S. et al (2019). The Oxford Handbook of Descartes and Cartesianism. Oxford: Oxford UP. [In Ukrainian]. Sententiae, 38(2), 112-115. https://doi.org/10.22240/sent38.02.112 
Laktionova, A. (2015). «Cogito Ergo Sum» and Philofsophy of Action. [In Ukrainian]. Sententiae, 32(1), 88-99. https://doi.org/10.22240/sent32.01.088

Lapointe, S., \& Pincock, C. (2017). Introduction. In S. Lapointe, \& C. Pincock (Eds.), Innovations in the History of Analytical Philosophy (pp. 1-23). London: Palgrave Macmillan. https://doi.org/10.1057/978-1-137-40808-2_1

Loeb, L. (1981). From Descartes to Hume. Ithaca: Cornell University Press.

O’Neill, E. (1987). Mind-Body Interaction and Metaphysical Consistency: A Defense of Descartes. Journal of the History of Philosophy, 25(2), 227-245. https://doi.org/10.1353/hph.1987.0026

Nadler, S. (1994). Descartes and Occasional Causation. British Journal for the History of Philosophy, 2(1), 35-54. https://doi.org/10.1080/09608789408570891

Nadler, S. (2005). Hope, Fear, and the Politics of Immortality. In T. Sorell. \& G. Rogers (Eds.), Analytic Philosophy and History of Philosophy (pp. 201-217). New York, Oxford: Oxford University Press.

Popper, K. (1953). Language and the Body-Mind Problem. Proceedings of the 11th International Congress of Philosophy, 7, 101-107. https://doi.org/10.5840/wcp1119537216

Popper, K. (1974). Objective Knowledge: Evolutionary Approach. New York, Oxford: Oxford University Press.

Radner, D. (1971). Descartes' Notion of the Union of Mind and Body. Journal of the History of Philosophy, 9(2), 159-170. https://doi.org/10.1353/hph.2008.1109

Radner, D. (1985). Is There a Problem of Cartesian Interaction? Journal of the History of Philosophy, 23(1), 35-49. https://doi.org/10.1353/hph.1985.0012

Richardson, R. C. (1982). The «Scandal» of Cartesian Interactionism. Mind, 91(361), 20-37. https://doi.org/10.1093/mind/XCI.361.20

Richardson, R. C. (1985). Union and Interaction of Body and Soul. Journal of the History of Philosophy, 23(2), 221-226. https://doi.org/10.1353/hph.1985.0038

Rorty, R. (1984). The historiography of philosophy: four genres. In R. Rorty, J. B. Schneewind, \& Q. Skinner (Eds.), Philosophy in History (pp. 49-75). Cambridge: Cambridge University Press. https://doi.org/10.1017/CBO9780511625534.006

Schmaltz, T. (2008). Descartes on Causation. New York, Oxford: Oxford University Press. https://doi.org/10.1093/acprof:oso/9780195327946.001.0001

Sepetyi, D. (2017). Descartes' mind-body dualism in the contemporary retrospective. [In Ukrainian]. Filosofska Dumka, (3), 64-73.

Sepetyi, D. (2018a). The Relationship between the Notions of the Substantial Union and the Interaction of Soul and Body in Descartes' Philosophy. [In Ukrainian]. Sententiae, 37(1), 136-152. https://doi.org/10.22240/sent37.01.136

Sepetyi, D. (2018b). Was Descartes a substance dualist? [In Ukrainian]. Actual Problems of Mind, (19), 36-63. https://doi.org/10.31812/apd.v0i19.2069

Sepetyi, D. (2019). Forty years after: reconsidering the problem of Descartes's Natural Institution theory vs the Coextension theory. Filosofska Dumka, (1), 106-119.

Smith, K. (2017). Descartes’ Theory of Ideas. Retrieved November 13, 2017 from Stanford Encyclopedia of Philosophy website: https://plato.stanford.edu/entries/descartes-ideas/\#ideasmodes

Wilson, M. (1978). Descartes. London, New York: Routledge.

Wilson, M. (1991). Descartes on the Origin of Sensation. Philosophical Topics, 19(1), 293-323. https://doi.org/10.5840/philtopics199119121

Received 18.10.2020 


\section{Dmytro Sepetyi}

\section{The problem of mind-body interaction and the causal principle of Descartes's Third Meditation}

The article analyses recent English publications in Cartesian studies that deal with two problems: (1) the problem of the intrinsic coherence of Descartes's doctrine of the real distinction and interaction between mind and body and (2) the problem of the consistency of this doctrine with the causal principle formulated in the Third Meditation. The principle at issue is alternatively interpreted by different Cartesian scholars either as the Hierarchy Principle, that the cause should be at least as perfect as its effects, or the Containment Principle, that the cause should contain all there is in its effects. The author argues that Descartes's claim (in his argument against the scholastic doctrine of substantial forms) that it is inconceivable how things of different natures can interact does not conflict with the acknowledgement of interaction between things of different natures in the case of soul and body. The case is made that Cartesian mindbody interaction can agree with both the Hierarchy Principle and the Containment Principle, because the Principle is about total and efficient cause, whereas in the interaction, mental and brain states are only partial (and plausibly, in the case of brains states, occasional) causes. In particular, in the case of the causality in the brain-to-mind direction, the mind is conditioned by brain states to form the corresponding specific ideas on the basis of its innate general ideas of movements, forms, colours, etc. Eventually, for Descartes, the most natural way to deal with worries about the possibility of mind-brain interaction is to rely on God's omnipotence, which certainly enables Him to arrange for such interaction.

\section{Дмитро Сепетий}

\section{Проблема психофізичної взаємодії та каузальний принцип Третьої Медитації Декарта}

У статті, на матеріалі англомовних декартознавчих досліджень, обговорюються дві проблеми: (1) проблема внутрішньої несуперечливості вчення Декарта про реальну відмінність і взаємодію ума й тіла та (2) проблема узгодженості цього вчення зі сформульованим у Третій Медитації каузальним принципом. Зазначений принцип тлумачиться різними декартознавцями або як Принцип Ієрархії, згідно з яким причина має бути не менш досконалою, аніж іiі наслідки, або як Принцип Вміщення, згідно з яким причина має містити в собі все, що міститься в її наслідках. Автор доводить, що Декартова апеляція (в аргументі проти схоластичного вчення про субстанційні форми) до незбагненності того, як речі різної природи можуть взаємодіяти, не суперечить визнанню взаємодії між речами різної природи у випадку душі й тіла. Обгрунтовано, що і Принцип Іерархії, і Принцип Вміщення можуть узгоджуватися з визнанням взаємодії між умом і тілом, оскільки Принцип стосується повної дієвої причини, тоді як у взаємодії, ментальні стани та фізичні стани мозку є лише частковими причинами. Зокрема, оскільки йдеться про спричинення в напрямку від тіла до ума, ум під впливом станів мозку формує відповідні специфічні ідеї на основі вроджених загальних ідей рухів, форм, кольорів тощо. Зрештою, у питанні про можливість психофізичної взаємодії для Декарта природно покладатися на всемогутність Бога, який напевно спроможний зробити так, щоб ум і тіло (мозок) людини взаємодіяли.

Dmytro Sepetyi, Doctor of Philosophical Sciences, Associate Professor of the Department of Social Studies at Zaporizhzhia State Medical University.

Дмитро Сепетий, д. філос. н., доцент кафедри суспільних дисциплін Запорізького держсавного медичного університету.

e-mail: dmitry.sepety@gmail.com 